Check for updates

Cite this: RSC Adv., 2018, 8, 33523

\title{
Adsorption of cadmium by live and dead biomass of plant growth-promoting rhizobacteria
}

\begin{abstract}
Xingjie Li, (D) Dongbo Li, Zhenning Yan and Yansong Ao*
Plant growth-promoting rhizobacteria (PGPR) have been extensively investigated in combination remediation with plants in heavy metal contaminated soil. However, being biosorbent, few studies of live and dead cells of PGPR have been undertaken. Meanwhile, the application of live or dead biomass for the removal of heavy metals continues to be debated. Therefore, this study uses living and non-living biosorbents of Cupriavidus necator GX_5, Sphingomonas sp. GX_15, and Curtobacterium sp. GX_31 to compare their $\mathrm{Cd}(॥)$ adsorption capacities by SEM-EDX, FTIR, and adsorption experiments. In the present study, whether the cells were living or dead and whatever the initial Cd(॥) concentration was, removal efficiency and adsorption capacity can be arranged as GX_31 > GX_15 > GX_5 ( $p<0.05)$. However, removal efficiency in live and dead biosorbents was quite different and it greatly affected by the initial Cd(I) concentrations. The dead cells exhibited a higher adsorption capacity than the live cells of GX_31. Nevertheless, for GX_5 and GX_15, the loading capacity of the non-living biomass was stronger than that of the living biomass at $20 \mathrm{mg} \mathrm{L}^{-1}$ of $\mathrm{Cd}(\Perp)$, but the capacity was similar at $100 \mathrm{mg} \mathrm{L}^{-1}$ of $\mathrm{Cd}(॥)$. Minor changes of spectra were found after autoclaving and it seemed that more functional groups of the dead biosorbent were involved in $\mathrm{Cd}(॥)$ binding by FTIR analysis, which also illustrated that the hydroxyl, amino, amide, and carboxyl groups played an important role in complexation with $\mathrm{Cd}(\mathrm{II})$. Based on these findings, we concluded that the dead cells were more potent for Cd(॥) remediation, especially for GX_31.
\end{abstract}

Received 13th August 2018

Accepted 15th September 2018

DOI: $10.1039 / c 8 r a 06758 a$

rsc.li/rsc-advances fungi, yeast, algae, industrial wastes, agricultural wastes, other polysaccharide materials, ${ }^{\mathbf{1 0}}$ and exogenous carbonaceous materials. ${ }^{11}$ The advantages of biosorption consist of a flexible operation, free availability, high adsorption capacity, low cost, and possible reuse..$^{12}$

Combination remediation refers to both plants and plant growth-promoting rhizobacteria (PGPR) or fungi involved in the process of remediation, which has been accepted as a promising approach for Cd(II) removal. ${ }^{13}$ PGPR are beneficial bacteria that colonize the rhizosphere of plants and facilitate plant growth and development by direct or indirect mechanisms. ${ }^{\mathbf{1 4}}$ Developing a fundamental knowledge of the interaction between PGPR and metal ions allows for a better understanding of the bioavailability of heavy metals in the soil, which is also imperative for the development of combination remediation technologies. PGPR not only promote growth and heavy metal uptake by plants, but they are also effective biosorbents for the adsorption of heavy metals, like other bacteria.

The adsorption of heavy metals using the biomass of live or dead bacteria, algae, and yeast has emerged as a potential strategy. ${ }^{15-17}$ For example, Tangaromsuk et al. investigated Cd(II) uptake by Sphingomonas paucimobilis biomass and reported that the removal capacity of live cells was markedly higher than that of dead cells. ${ }^{18} \mathrm{Xu}$ et al. reported that both dead and live cells of Enterobacter cloacae TU had the ability to remove Cd(II), and that live cells were superior to dead cells. ${ }^{19}$ Conversely, a study 
conducted by Huang et al. demonstrated that dead cells could adsorb cadmium to a greater degree than living cells. ${ }^{20}$ Guo et al. also observed that the live and dead biomass of Pseudomonas plecoglossicida demonstrated almost the same uptake capacities for Cd(II). ${ }^{21}$ Despite previous research, however, there continues to be a lack of information about the comparative study of live and dead cells for Cd(II) removal. There are also debates about removal capacities for heavy metals between live and dead cells based on the studies mentioned above. Moreover, little work has been done to compare the adsorption of Cd(II) using the live and dead biomass of various PGPR under different concentrations of $\mathrm{Cd}(\mathrm{II})$. As a result, the debated question about the use of live or dead biomass for the removal of heavy metals remains.

The objectives of this study are: (1) to investigate the capacities of PGPR (i.e. Cupriavidus necator GX_5 (CP002878), Sphingomonas sp. GX_15 (MF959440), and Curtobacterium sp. (MF959445) GX_31) for Cd(II) adsorption under the same experimental conditions; (2) to analyse morphology and functional group changes of live and dead cells after interaction with Cd(II) using SEM-EDX and FTIR; (3) to compare the removal capacities of the live and dead biomass of these strains; and (4) to evaluate the advantages of live and dead biosorbents for the remediation of contaminated sites.

\section{Materials and methods}

\subsection{Bacterial strains and growth conditions}

In this study, three PGPR, Gram-positive strain Curtobacterium sp. GX_31 (MF959445) and Gram-negative strains Cupriavidus necator GX_5 (CP002878) and Sphingomonas sp. GX_15 (MF959440) were used, and isolated from a 60 year-old leadzinc core from rhizosphere soil of local (Guangxi, China) dominant plants, with an average Cd(II) concentration of $59.43 \mathrm{mg} \mathrm{kg}^{-1}$. The strains were cultured in a Luria-Bertani (LB) broth medium and maintained at $28{ }^{\circ} \mathrm{C}$.

\subsection{Preparation of the live and dead biosorbents}

The strains were incubated in a LB culture medium at $\mathrm{pH} 7.0 \pm$ 0.2 on a rotary shaker at $28^{\circ} \mathrm{C}$, with a rotating speed of $180 \mathrm{rpm}$. After 24 hours of incubation, the cultured cells were harvested and washed three times with sterile deionized distilled water $\left(\mathrm{ddH}_{2} \mathrm{O}\right)$, and then separated by centrifugation at $10000 \times g$ for 10 min at $4{ }^{\circ} \mathrm{C}$, collected, pre-cooled at $-80^{\circ} \mathrm{C}$, and lyophilized overnight in a Labconco freeze dryer. ${ }^{22}$ The dried cells were ground into a fine powder and used as the live biosorbent. For the dead biomass, the cultured bacterial suspensions were firstly autoclaved at $121{ }^{\circ} \mathrm{C}$ for $20 \mathrm{~min}$. Next, the non-living cells were collected, lyophilized, and ground into a powder just as for the live cells mentioned above, and were used as the dead biosorbent.

\subsection{Preparation of Cd(II) solutions}

A Cd(II) stock solution of $1000 \mathrm{mg} \mathrm{L}^{-1}$ was prepared by dissolving $\mathrm{CdCl}_{2} \cdot 2.5 \mathrm{H}_{2} \mathrm{O}$ in Milli-Q water. Working $\mathrm{Cd}(\mathrm{II})$ solutions were prepared by diluting the stock solution to the desired concentrations, which were used for Cd(II) adsorption experiments of the live and dead biomass. The initial $\mathrm{pH}$ of the working solutions was adjusted to 6.0 by the addition of $0.1 \mathrm{~mol} \mathrm{~L}^{-1} \mathrm{HCl}$ or $\mathrm{NaOH}$ solution. All the chemicals used in this study were of analytical grade and the solutions were prepared using Milli-Q water.

\subsection{Adsorption experiments of $\mathrm{Cd}$ (II) by live and dead biosorbents}

The adsorption behaviours of the live and dead biomass were conducted at $28{ }^{\circ} \mathrm{C}$ by mixing $0.02 \mathrm{~g}$ of each biosorbent in $50 \mathrm{~mL}$ plastic tubes with $20 \mathrm{~mL}$ of 20,50 , and $100 \mathrm{mg} \mathrm{L}{ }^{-1}$ working solution. In other words, the concentration of the biomass was $1 \mathrm{~g} \mathrm{~L}^{-1}$ of dry cells. The mixture was shaken at $180 \mathrm{rpm}$ for 6 hours on a shaker and then centrifuged at $10000 \times g$ for $10 \mathrm{~min}$. Next, the concentration of Cd(II) in the supernatant was determined by ICP (inductively coupled plasma). The difference between the initial Cd(II) concentration and the equilibrium ion concentration was assumed to have been adsorbed by the live or dead cells. The removal efficiency adsorption (\%) for Cd(II) was calculated using the following eqn (1):

$$
\operatorname{adsorption}(\%)=\frac{C_{0}-C_{\mathrm{eq}}}{C_{0}} \times 100
$$

where $C_{0}$ and $C_{\text {eq }}$ are the initial and equilibrium $\mathrm{Cd}(\mathrm{II})$ concentrations, respectively, in the supernatant $\left(\mathrm{mg} \mathrm{L}^{-1}\right)$. The adsorption capacity (AC, $\mathrm{mg} \mathrm{g}^{-1}$ ) was calculated using eqn (2):

$$
\mathrm{AC}\left(\mathrm{mg} \mathrm{g}^{-1}\right)=\frac{\left(C_{0}-C_{\mathrm{eq}}\right) \times V}{m}
$$

where $C_{0}$ and $C_{\text {eq }}$ are the same as in eqn (1), $m(\mathrm{~g})$ is the weight of the biosorbent, and $V(\mathrm{~L})$ is the volume of the working solution. Also, parallel assays without strains were carried out as controls to ensure that no adsorption occurred on the walls of the plastic tubes. All the experiments were conducted in triplicate.

\subsection{SEM-EDX observation}

The surface structure and morphology of live and dead biosorbents before and after interaction with $\mathrm{Cd}$ (II) was studied using a SEM (Sirion 200, USA). For SEM analysis, 0.02 of $g$ lyophilized samples of live and dead cells were mixed with $20 \mathrm{~mL}$ of the $\mathrm{Cd}(\mathrm{II})$ working solution $\left(100 \mathrm{mg} \mathrm{L}^{-1}\right)$. After adsorption, the centrifugally collected cells were fixed with $2.5 \%$ glutaraldehyde at $4{ }^{\circ} \mathrm{C}$ overnight. The fixed samples were then smeared on the coverslip, air dried, dehydrated using a gradient series with ethanol (30\%, 50\%, 70\%, 90\% and 100\%) for $15 \mathrm{~min}$ each, and sputter-coated with gold. ${ }^{23}$ Energy dispersive X-rays (EDX) of both the live and dead biosorbents before and after the interaction with Cd(II) were simultaneously analysed.

\subsection{Fourier transformed infrared (FTIR) spectroscopy analysis}

Infrared spectra of the live and dead biomass loaded with and without Cd(II) were obtained using a FTIR spectrometer (Nicolet $6700, \mathrm{USA})$ at room temperature. Cd(II)-loaded $\left(100 \mathrm{mg} \mathrm{L}^{-1}\right)$ 
samples of live and dead biosorbents were freeze-dried overnight. Then, $1 \mathrm{mg}$ of dried cells was mixed and ground with $100 \mathrm{mg}$ of $\mathrm{KBr}$ in an agate mortar to obtain the samples. Finally, the samples were immediately recorded with the spectrometer in the range of $4000-400 \mathrm{~cm}^{-1}$ with a resolution of $4 \mathrm{~cm}^{-1}$ in order to investigate the functional groups and possible $\mathrm{Cd}(\mathrm{II})$ binding sites. ${ }^{24}$

\subsection{Statistical analysis}

Data were subjected to analysis of variance and are represented as the mean \pm standard deviation. Pairwise differences among treatments were tested using least significant difference at $p=$ 0.05 . All the statistical analyses were performed using SAS8.1 software.

\section{Results and discussion}

\subsection{Removal efficiency and adsorption capacity of live and dead biosorbents}

Under optimal conditions (pH, 6.0; reaction time, $6 \mathrm{~h}$; biomass dosage, $1.0 \mathrm{~g} \mathrm{~L}^{-1}$ ) based on the preliminary data, ${ }^{25}$ the adsorption experiments for $\mathrm{Cd}(\mathrm{II})$ of live and dead biosorbents of the three PGPR (Cupriavidus necator GX_5, Sphingomonas sp. GX_15, and Curtobacterium sp. GX_31) were conducted with initial Cd(II) concentrations of 20,50 , and $100 \mathrm{mg} \mathrm{L}^{-1}$. There were significant differences in the removal efficiency and adsorption capacity of live and dead biosorbents between the three strains, and the ranking can be ordered as GX_31 > GX_15 $>$ GX_5 ( $p<0.05)$, whatever the initial Cd(II) concentration is (20, 50 or $100 \mathrm{mg} \mathrm{L}^{-1}$ ) (Fig. 1 and 2). Other biosorbents have also been used for $\mathrm{Cd}(\mathrm{II})$ adsorption. For example, the maximum sorption capacity of NTAA-LCM for Cd(II) reached $143.4 \mathrm{mg} \mathrm{g}^{-1}$ with an initial $\mathrm{Cd}(\mathrm{II})$ concentration of $200 \mathrm{mg} \mathrm{L}^{-1},{ }^{26}$ higher than that in this study (31.28 and $35.09 \mathrm{mg} \mathrm{g}^{-1}$ for the live and dead biomass of GX_31 with $100 \mathrm{mg} \mathrm{L^{-1 }}$ of Cd(II)) (Fig. 2). On the contrary, the $\mathrm{Cd}(\mathrm{II})$ adsorption capacity of Penicillium simplicissimum was $21.5 \mathrm{mg} \mathrm{g}^{-1},{ }^{27}$ lower than that of GX_31. In another investigation, the maximum adsorption capacity of the dry waste biofilms for $\mathrm{Cd}(\mathrm{II})\left(42 \mathrm{mg} \mathrm{g}^{-1}\right)$ was also higher. However, the removal efficiency of $\mathrm{Cd}(\mathrm{II})$ was $89.3 \%,{ }^{28}$ which was lower than that of the dead biosorbent of GX_31 (98.27\%) (Fig. 1B). It seems that the results from different studies may not be directly comparable on account of differences in experimental conditions, ${ }^{29}$ but it is reasonable to make a comparison in the present study under the same conditions. The adsorption capacity and removal efficiency varied among the live and dead biomass of these strains due to their own adsorption mechanisms. ${ }^{30}$

Regarding the live biosorbent of the same strain, whatever the strain was, the removal efficiency and adsorption capacity also had significant variations under different $\mathrm{Cd}(\mathrm{II})$ concentrations (Fig. 1A and 2A). Fig. 1A shows that the removal efficiency was clearly higher under a lower $\mathrm{Cd}(\mathrm{II})$ concentration than under a higher $\mathrm{Cd}(\mathrm{II})$ concentration, which adheres to findings in other investigations. ${ }^{31,32}$ At a lower Cd(II) concentration, there were easily enough free binding sites of live biosorbent for $\mathrm{Cd}(\mathrm{II})$ to interact, which resulted in a high removal efficiency. Therefore, the maximum $\mathrm{Cd}(\mathrm{II})$ removal efficiency of the live biomass of GX_5, GX_15 and GX_31 displayed with an initial $\mathrm{Cd}$ (II) concentration of $20 \mathrm{mg} \mathrm{L}^{-1}$ was $25.21 \%, 55.79 \%$ and $87.03 \%$, respectively, and the minimum removal efficiency was $11.48 \%, 29.16 \%$ and $31.45 \%$, respectively (100 mg L $\mathrm{L}^{-1}$ of $\mathrm{Cd}(\mathrm{II})$ ) (Fig. 1A). On the other hand, the adsorption capacity of live biosorbent increased significantly with an increasing initial $\mathrm{Cd}(\mathrm{II})$ concentration for an identical strain (Fig. 2A), which was consistent with the study by Cheng et $a .^{33}$ The strongest and weakest adsorption capacities were $12.31,21.83$, and $31.28 \mathrm{mg} \mathrm{g}^{-1}$ and $6.98,15.44$, and $24.08 \mathrm{mg}$ $\mathrm{g}^{-1}$ for GX_5, GX_15, and GX_31 at $100 \mathrm{mg} \mathrm{L}^{-1}$ and $20 \mathrm{mg} \mathrm{L}^{-1}$ of Cd(II), respectively (Fig. 2A). Considering the same amount of biomass dosage, a high initial concentration could supply a driving force to interact with limited Cd(II) binding sites and facilitate adsorption by the live biomass. ${ }^{34}$

There was also a significant difference in the removal efficiency for $\mathrm{Cd}(\mathrm{II})$ of the dead biosorbent of the same strain under different $\mathrm{Cd}(\mathrm{II})$ concentrations (Fig. 1B). This displayed the same tendency as that of the live biosorbent, namely, that the removal efficiency decreased along with the increasing initial $\mathrm{Cd}(\mathrm{II})$ concentration, because at a high $\mathrm{Cd}(\mathrm{II})$ concentration, a lack of adequate binding sites restricted the removal efficiency. ${ }^{35}$ Fig. 1B shows that the highest and lowest removal efficiencies of the dead biosorbents of GX_5, GX_15, and GX_31 were $32.95 \%, 63.77 \%$, and $98.27 \%$ and $12.09 \%, 18.58 \%$, and $32.51 \%$ under 20 and $100 \mathrm{mg} \mathrm{L}^{-1}$ of $\mathrm{Cd}(\mathrm{II})$, respectively. However, the adsorption capacity of the dead biosorbent did not show the same tendency as the live biosorbent did, except GX_5, which had the largest and smallest adsorption capacities of 12.97 and $9.12 \mathrm{mg} \mathrm{g}^{-1}$ at 100 and $20 \mathrm{mg} \mathrm{L}^{-1}$ of Cd(II), respectively (Fig. 2B). For the dead biomass of GX_15 and GX_31, the adsorption capacity increased with a higher metal concentration and it reached a saturation value due to finite binding sites. When the concentration of $\mathrm{Cd}$ (II) changed from 20 to $50 \mathrm{mg} \mathrm{L}^{-1}$, the adsorption capacities varied from 17.65 to $18.87 \mathrm{mg} \mathrm{L}^{-1}$ for GX_15 and 27.19 to $35.09 \mathrm{mg} \mathrm{L}^{-1}$ for GX_31 (Fig. 2B). A higher $\mathrm{Cd}(\mathrm{II})$ concentration did not lead to a higher adsorption capacity. This phenomenon agrees with the study by Khadivinia et al., who point out that at a higher $\operatorname{Cd}($ II) concentration, the binding sites become fewer and the biosorbent sites adsorb metal ions more quickly at lower concentrations, which leads to the decrease of adsorption yield. ${ }^{36}$

\subsection{SEM-EDX analysis}

The surface structure and cell morphology changes of the live and dead biosorbent were determined by SEM coupled with EDX before and after interaction with $100 \mathrm{mg} \mathrm{L}^{-1}$ of $\mathrm{Cd}(\mathrm{II})$, as depicted in Fig. 3 and 4. Before adsorption, all the live biosorbents were observed to be rod shapes with clear boundaries (Fig. 3A-a-C-a) and the dead biosorbents evidently seemed to join together, especially for GX_5 and GX_15 (Fig. 3B-a and D-a). However, after binding, the surfaces of both live and dead cells became rough, irregular, and noticeably covered with silvery white sediments (Fig. 3). The SEM micrographs also indicated 

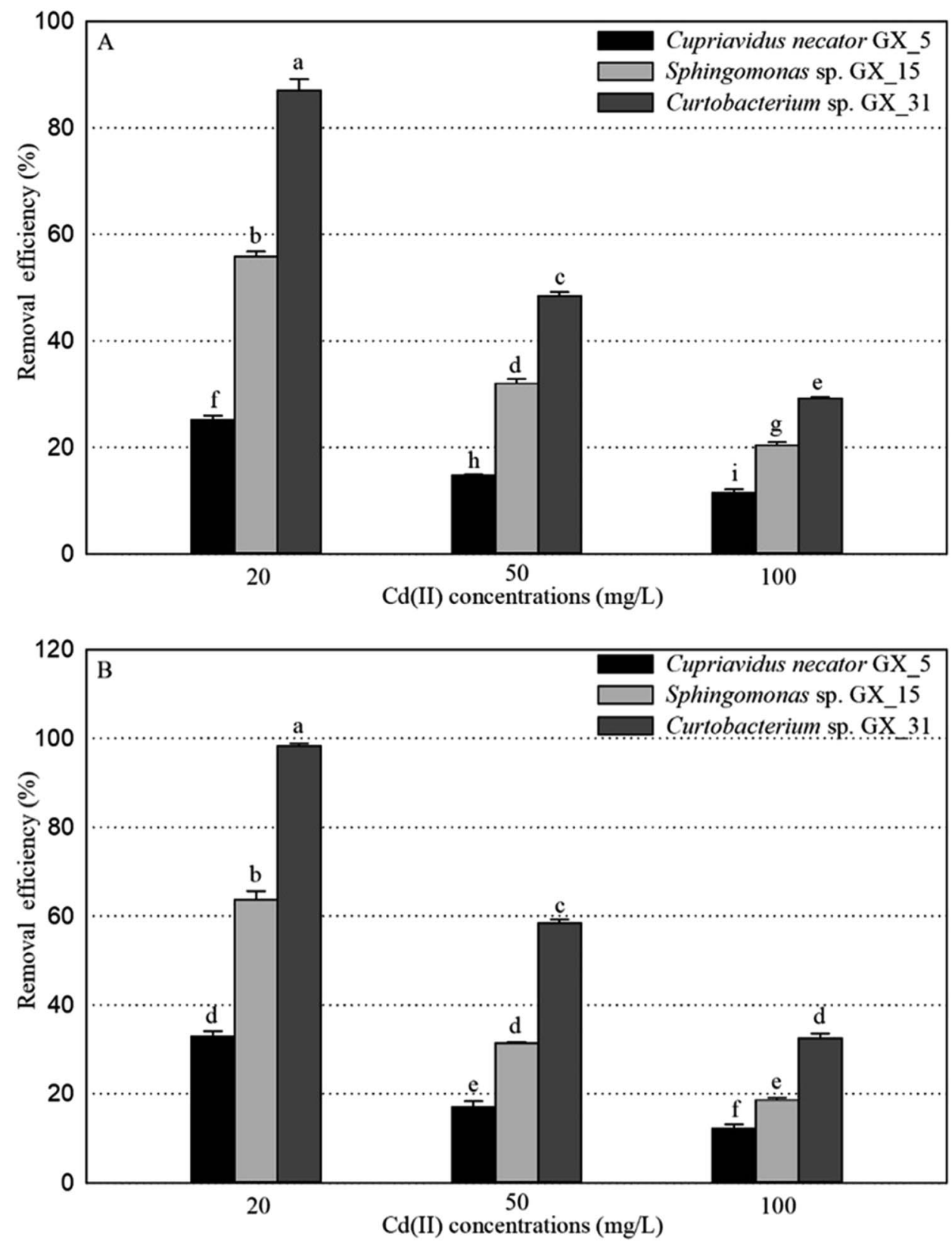

Fig. 1 The removal efficiency for $\mathrm{Cd}(\Perp)$ of live (A) and dead (B) biosorbents of Cupriavidus necator Gx_5, Sphingomonas sp. Gx_15, and Curtobacterium sp. Gx_31 under 20, 50, and $100 \mathrm{mg} \mathrm{L}^{-1}$ of initial Cd(॥) concentrations.

that $\mathrm{Cd}(\mathrm{II})$ exposure caused anomalous aggregation of the $L$. plantarum CCFM8610.$^{37}$ Similarly, the surface of the live and dead biomass of Spirulina sp. became rough after Cd(II) uptake, ${ }^{38}$ which was in accordance with the SEM observations. For GX_15, some floccus precipitation was found on their surfaces (Fig. 3C and D), which was also observed by Lin et al. ${ }^{39}$ As pointed out in another study, after Cd(II) adsorption, more flocculated sediments appeared near the cell surface of $E$. cloacae TU. ${ }^{19}$ Likewise, under heavy metal stress, many flocculated particles could be discovered, which suggested the presence of heavy metals on the cell wall. ${ }^{40} \mathrm{EDX}$ spectra recorded the signals of carbon, nitrogen, oxygen, sodium, magnesium, and calcium, which were likely in the polysaccharides and proteins of the biomass (Fig. 4). No $\mathrm{Cd}(\mathrm{II})$ signals were detected in unloaded biosorbent, but clear peaks for $\mathrm{Cd}(\mathrm{II})$ were observable after $\mathrm{Cd}(\mathrm{II})$ exposure, which indicates the presence of $\mathrm{Cd}(\mathrm{II})$ in the biosorbents after adsorption. SEM-EDX confirmed that both the live and dead biomass of these strains had potential for Cd(II) remediation in cadmium polluted environments. SEMEDX is a useful tool for visual confirmation of surface morphology changes of cells after absorbing metal ions and it has been extensively applied in research..$^{24,41,42}$

\subsection{FTIR analysis}

The surface functional group of the biosorbent is an important factor for metal adsorption. FTIR spectra of the live and dead biosorbents of GX_5, GX_15, and GX_31 were recorded before 

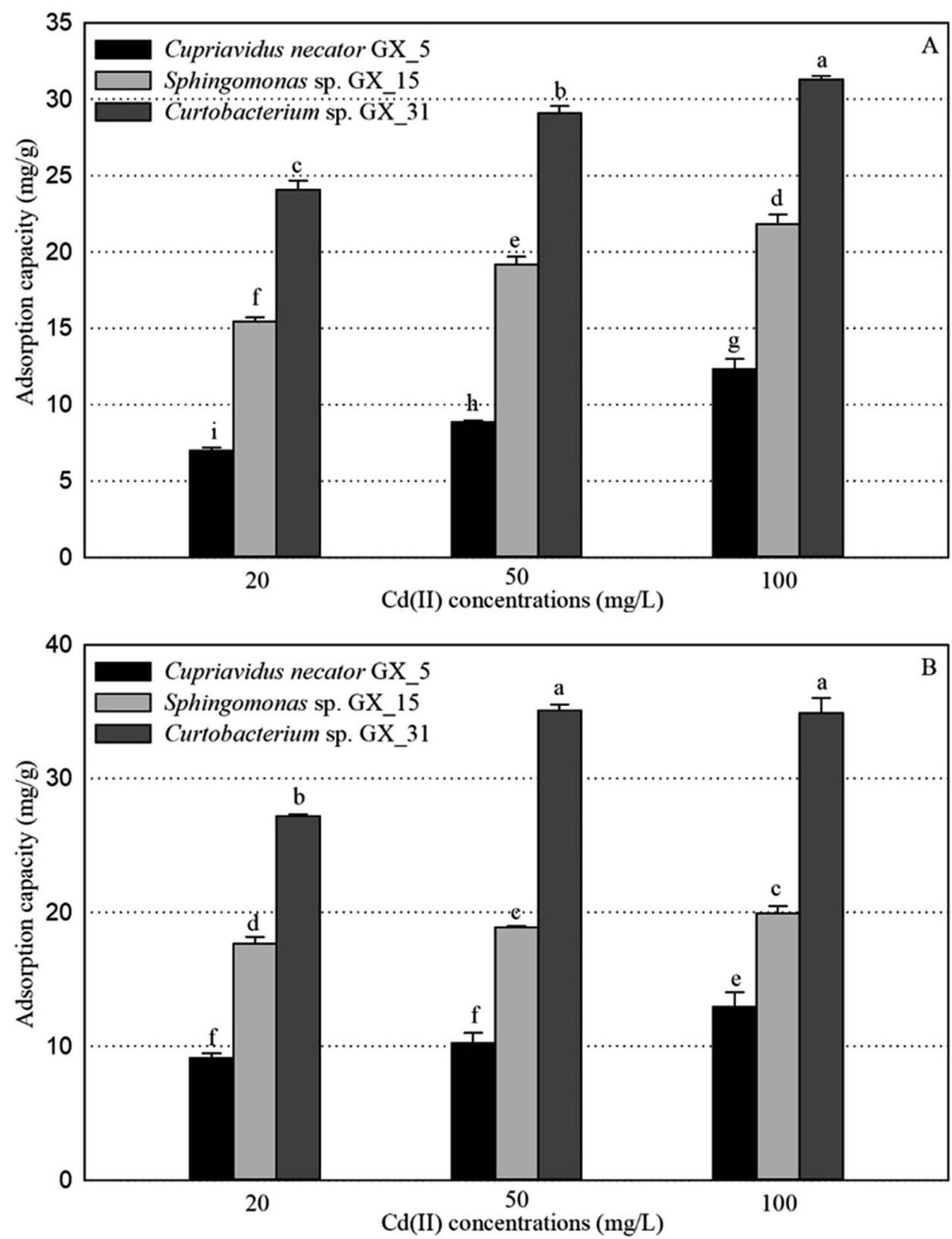

Fig. 2 The adsorption capacity for $\mathrm{Cd}(\Perp)$ of live (A) and dead (B) biosorbents of Cupriavidus necator Gx_5, Sphingomonas sp. Gx_15, and Curtobacterium sp. Gx_31 under 20,50, and $100 \mathrm{mg} \mathrm{L}^{-1}$ of initial Cd(॥) concentrations.

and after Cd(II) uptake. Fig. 5 shows various functional groups present on the cell surface, and reveals the complex nature of these strains. The spectra of GX_15 and GX_31 are similar to each other but they differ from GX_5, especially in the region of 1400-700 $\mathrm{cm}^{-1}$.

In this study, live and dead cells displayed similar spectra, and all the characteristic peaks were present on both biosorbents, which was in consistent with other studies (Fig. 5). ${ }^{\mathbf{1 6 , 4 3 , 4 4}}$ Broad bands in the range of $3200-3500 \mathrm{~cm}^{-1}$ correspond to the hydroxyl group as well as the $-\mathrm{NH}$ bond of the amino group. ${ }^{45}$ Two peaks at approximately 2930 and $2850 \mathrm{~cm}^{-1}$ were ascribed to symmetric and asymmetric - $\mathrm{CH}$ vibration in lipids. ${ }^{36}$ The band at $1741 \mathrm{~cm}^{-1}$ represented the carbonyl group in the polyhydroxyalkanoic acid, identified by nuclear magnetic resonance analysis of a chloroform extract. ${ }^{46}$ The peak positions around 1655 and 1543 reflected the presence of amide I (-COstretching vibration) and amide II (-NH bending and $-\mathrm{CN}$ stretching) in proteins, respectively. ${ }^{47}$ Peaks at 1240 and $1071 \mathrm{~cm}^{-1}$ were assigned to the alcoholic $-\mathrm{CN}$ and -COstretching vibration, revealing the presence of amino and hydroxyl groups, ${ }^{48}$ and a band at $1400 \mathrm{~cm}^{-1}$ also represented a hydroxyl group. ${ }^{27}$ The $-\mathrm{CO}-,-\mathrm{CN}, \mathrm{P}=\mathrm{O}$, and $\mathrm{S}=\mathrm{O}$ stretching vibrations all existed at the band at about $1291.09 \mathrm{~cm}^{-1} .^{49} \mathrm{An}$ adsorption band was positioned at $1080 \mathrm{~cm}^{-1}$, corresponding to the -CO- group vibration in the cyclic structure of carbohydrates. ${ }^{36}$ 

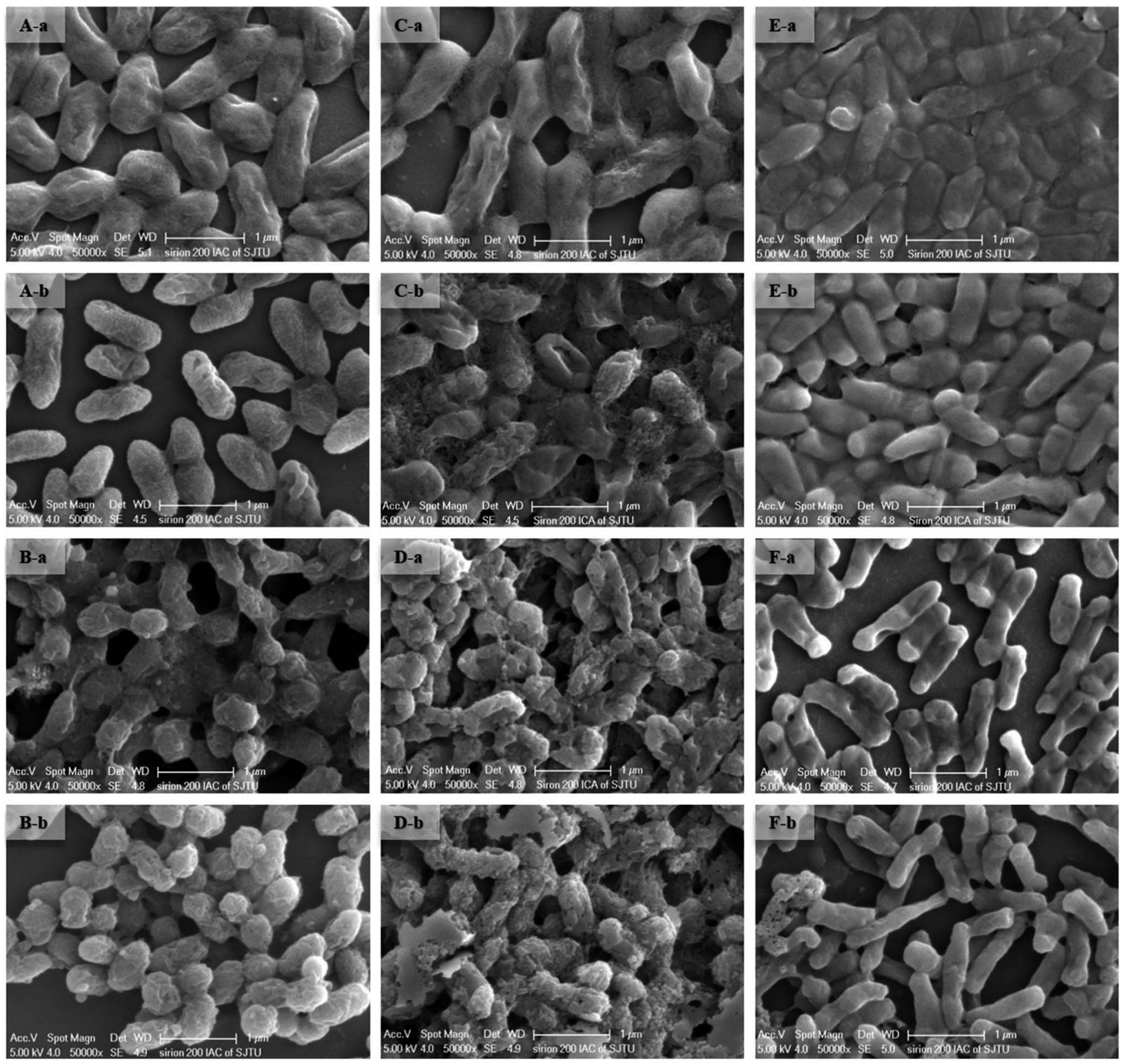

Fig. 3 SEM images of live and dead biosorbents of Cupriavidus necator Gx_5 (live: A, and dead: B), Sphingomonas sp. Gx_15 (live: C, and dead: D), and Curtobacterium sp. Gx_31 (live: E, and dead: F) before (A) and after (B) interaction with $100 \mathrm{mg} \mathrm{L}^{-1}$ of $\mathrm{Cd}(\Perp)$.

Although they had similar spectra, there were minor changes when we compared the spectra between live and dead biosorbents before adsorption. The bands were shifted from $3307.31,1655.52,1543.01$, and $1292.01 \mathrm{~cm}^{-1}$ to 3415.13 , $1649.69,1544.36$, and $1306.15 \mathrm{~cm}^{-1}$ for GX_5 (Fig. 5A-a and Ba); from 1653.55 , and $1397.42 \mathrm{~cm}^{-1}$ to 1656.04 , and $1396.81 \mathrm{~cm}^{-1}$ for GX_15 (Fig. 5C-a and D-a); and from 3308.16, 1545.35, and $1070.29 \mathrm{~cm}^{-1}$ to $3402.35,1537.05$, and $1067.42 \mathrm{~cm}^{-1}$ for GX_31 (Fig. 5E-a and F-a), which indicated that autoclave had some effect on the functional groups, though not significant.

After adsorption, for GX_5, shifts were observed for the live biomass from 3307.31 , and $1741.17 \mathrm{~cm}^{-1}$ to 3367.98 , and $1728.50 \mathrm{~cm}^{-1}$, and from $3415.13,1649.69$, and $1544.36 \mathrm{~cm}^{-1}$ to
$3305.5,1656.34$, and $1536.76 \mathrm{~cm}^{-1}$ for dead biomass, revealing that hydroxyl, amino, carbonyl, or amide groups were involved for binding Cd(II) (Fig. 5A and B). Fig. 5C and D show that peaks at $1653.55,1397.42$, and $1082.43 \mathrm{~cm}^{-1}$ of live cells of GX_15 shifted to $1656.25,1398.12$, and $1065.38 \mathrm{~cm}^{-1}$, while bands down shifted from 3303.36, 1656.04, 1543.38, 1396.81, 1241.26, and $1082.56 \mathrm{~cm}^{-1}$ to $3294.93,1649.44,1535.39,1390.04$, 1234.50 , and $1058.79 \mathrm{~cm}^{-1}$, indicating that hydroxyl, amino, amide, or carboxyl groups were responsible for the $\mathrm{Cd}(\mathrm{II})$ removal. However, it seemed that more bands were involved in the adsorption of $\mathrm{Cd}(\mathrm{II})$ in the dead biosorbent, which corresponds to the findings of a previous study by Huang et al. ${ }^{20}$ In the case of GX_15, the peaks of live cells at 3308.16, 1399.15 and $1070.29 \mathrm{~cm}^{-1}$ were shifted to $3401.02,1402.46$, and 

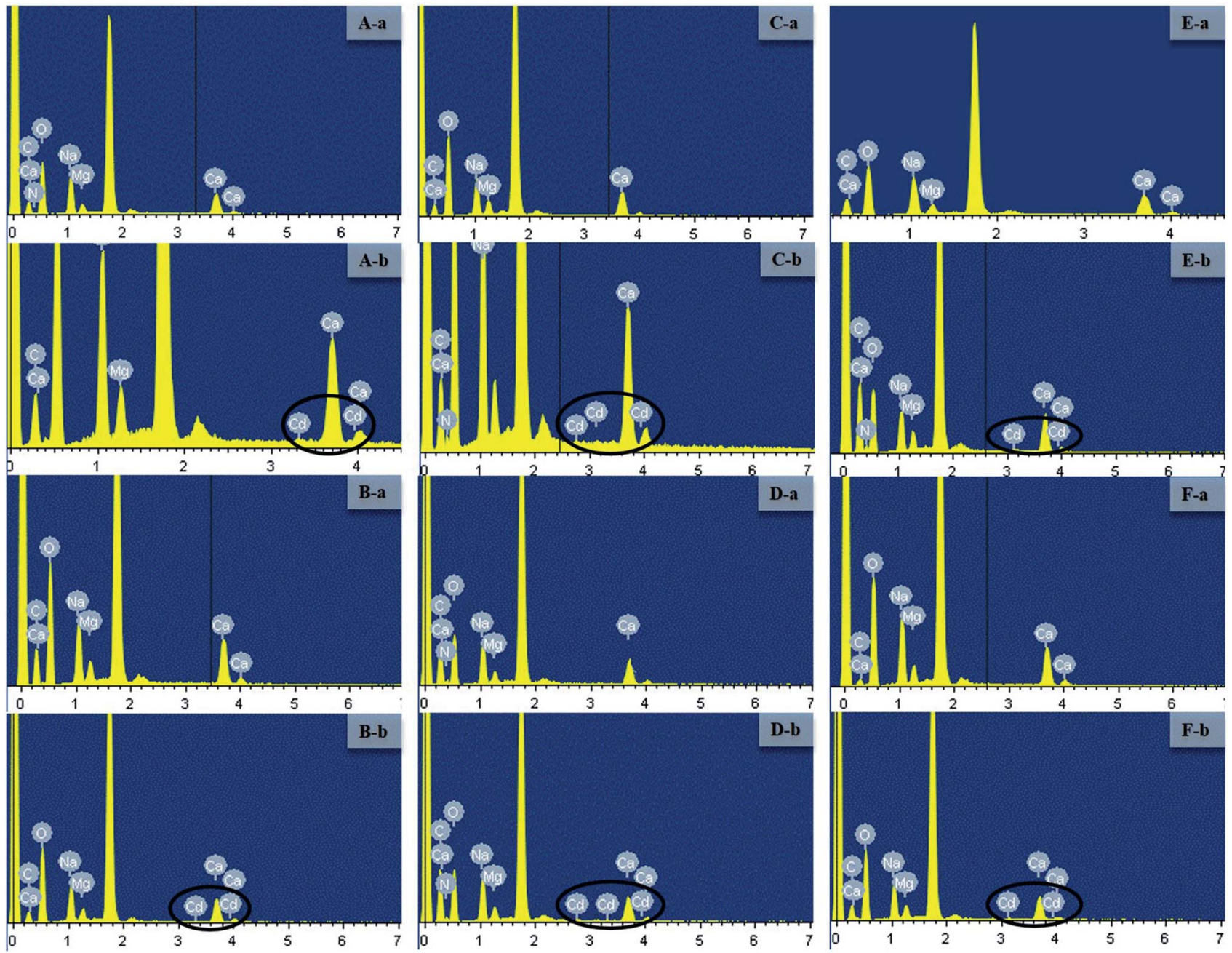

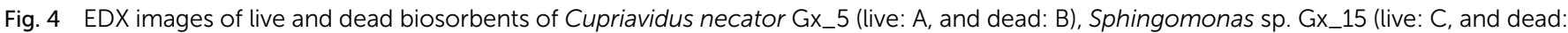
D), and Curtobacterium sp. Gx_31 (live: E, and dead: F) before (A) and after (B) interaction with 100 mg $L^{-1}$ of Cd(ı).

$1067.89 \mathrm{~cm}^{-1}$ and those of dead cells, 3402.35, 1655.78, 1401.23, 1238.19, and $1067.42 \mathrm{~cm}^{-1}$ to $3409.65,1651.22$, 1403.42, 1233.52, and $1065.79 \mathrm{~cm}^{-1}$ (Fig. 5E and F), demonstrating that hydroxyl, amino, carboxyl, or amide groups played an important role for Cd(II) adsorption. It also appeared that more groups participated in $\mathrm{Cd}(\mathrm{II})$ binding.

The present FTIR spectra analysis provides evidence that functional groups like hydroxyl, amino, amide, carbonyl, and carboxyl groups are involved in the binding of Cd(II) on surface of both live and dead biosorbents. Such findings have also been reported in other research. ${ }^{50-53}$

\subsection{Live and dead biosorbent comparison}

The removal efficiencies for Cd(II) of live and dead biosorbents of GX_5, GX_15, and GX_31 were compared, with different Cd(II) concentrations. It was clear that the performance of the removal efficiency was different between the live and dead biomass of these three strains (Fig. 6). The Cd(II) removal capacity of dead cells was markedly higher than that of live cells with an initial Cd(II) concentration of $20 \mathrm{mg} \mathrm{L}^{-1}$ for all the strains (Fig. 6). The increase of the metal adsorption capacity of the dead biomass can be explained in the following ways. A loss of cell membrane integrity during autoclaving allows the exposure of binding sites inside the cell. ${ }^{16}$ According to the hypothesis, an increase of $\mathrm{Cu}(\mathrm{II})$ adsorption by Penicillium spinulosum and of $\mathrm{U}$ uptake by $S$. cerevisiae cells permeabilized by the action of detergents ${ }^{53}$ or by the action of $\mathrm{HCHO}$ or $\mathrm{HgCl}_{2},{ }^{54}$ respectively, was also described. Machado assessed the membrane integrity of heat-treated $S$. cerevisiae cells with propidium iodide by fluorescence microscopy and observed membrane integrity was lost during the thermal treatment. ${ }^{44}$ In addition, more functional groups are involved in $\mathrm{Cd}$ (II) uptake as depicted in the former section. $\mathrm{Li}$ et al. also pointed out that in their study more functional groups participated in the adsorption processes of the dead biomass, compared with those linked to the live biomass. ${ }^{55}$ The third reason is the efflux mechanism of live cells, which could reduce Cd(II) adsorption. The most frequent mechanism of toxic divalent cation resistance is energy-dependent pumping out, that is membrane efflux pumps. ${ }^{56}$ Many studies have focused on the Cd(II) efflux mechanism of live cells for coping with high Cd(II) stress. ${ }^{57,58}$ When the $\mathrm{Cd}(\mathrm{II})$ concentrations were 50 and $100 \mathrm{mg} \mathrm{L}^{-1}$, the dead cells of GX_31 still outperformed the live 

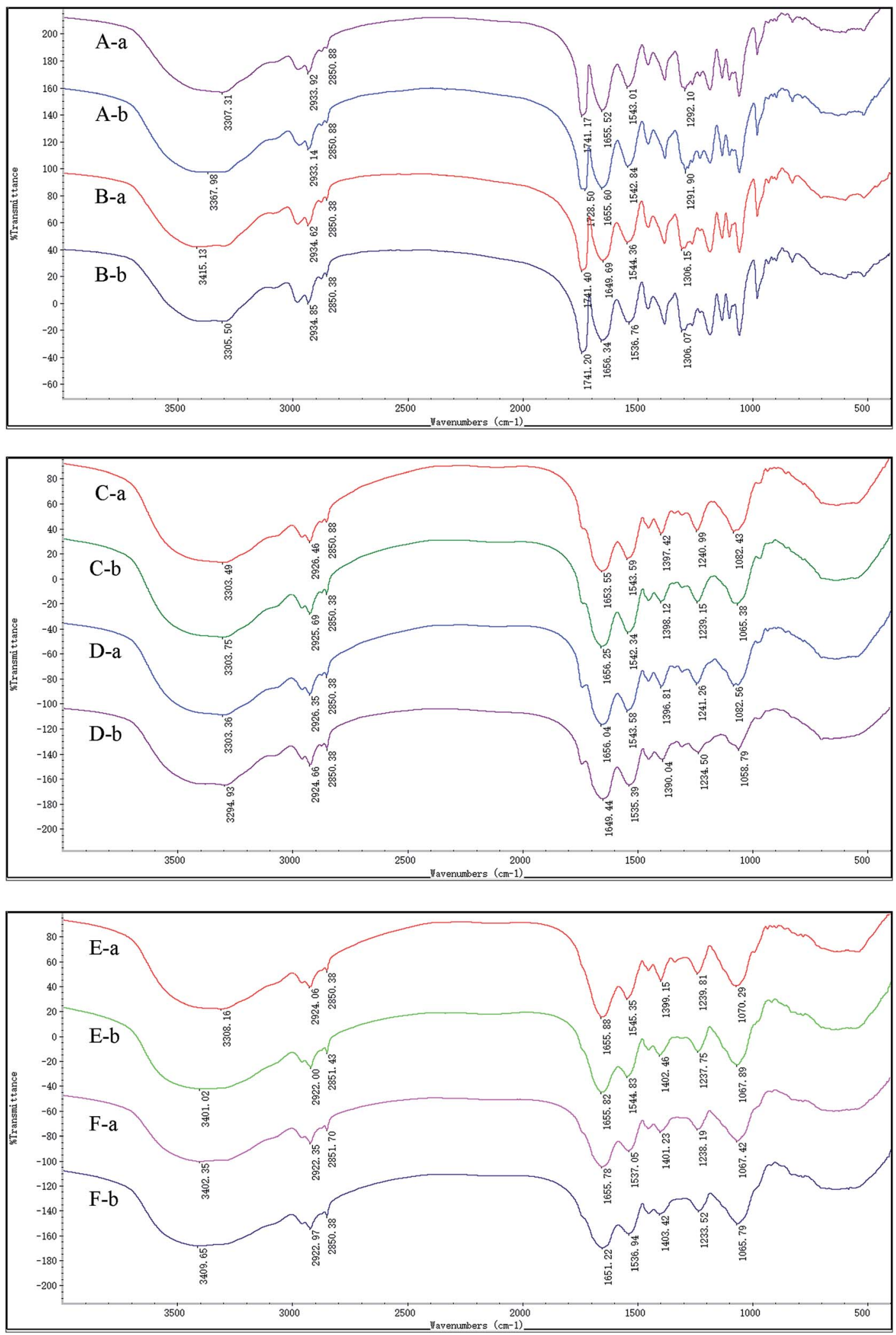

Fig. 5 FTIR images of live and dead biosorbents of Cupriavidus necator Gx_5 (live: A, and dead: B), Sphingomonas sp. Gx_15 (live: C, and dead:

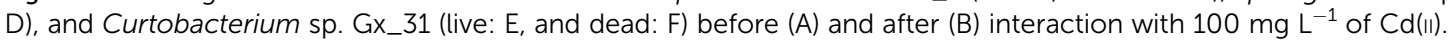

cells (Fig. 6C). However, for GX_15, the adsorption efficiency of the live biomass was observed to be slightly higher, but there were no differences in the dead biomass (Fig. 6B). Similarly, the adsorption capacity of GX_5 was significantly higher in the dead biosorbent than in the live biosorbent with a Cd(II) concentration of $50 \mathrm{mg} \mathrm{L}^{-1}$. On the contrary, under a $\mathrm{Cd}(\mathrm{II})$ concentration 

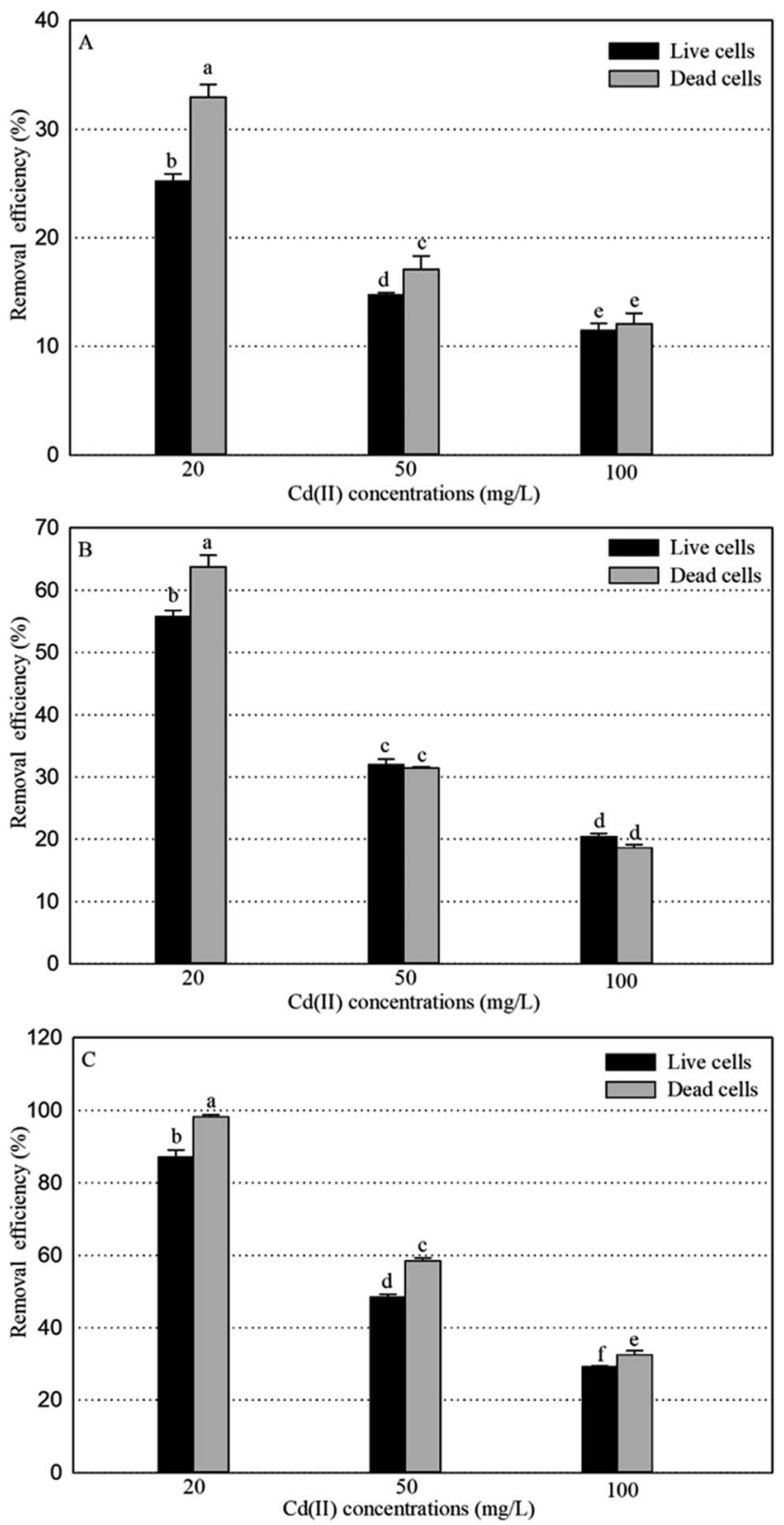

Fig. 6 The removal efficiency for $\mathrm{Cd}(॥)$ of live and dead biosorbents of Cupriavidus necator Gx_5 (A), Sphingomonas sp. Gx_15 (B), and Curtobacterium sp. Gx_31 (C) under 20, 50, and $100 \mathrm{mg} \mathrm{L}^{-1}$ initial Cd(॥) concentrations.

of $100 \mathrm{mg} \mathrm{L}^{-1}$, the metal loading capacity of the dead cells of GX_5 was equivalent to that of the living cells (Fig. 6A).

With an increase of the $\mathrm{Cd}(\mathrm{II})$ concentration, the adsorption efficiency of the live biomass got close to that of the dead biomass, which may be because of the additional intercellular accumulation of living cells. ${ }^{2}$ The initial Cd(II) concentration had a significant effect on the adsorption. However, in this study, the live biosorbents did not exhibit a significantly higher adsorption capacity than the dead biosorbents, which is reported by other researchers. ${ }^{18,38}$ The adsorption capacity of the live cells may be greater to, equal to, or less than that of the dead cells and it may depend on the bacteria under consideration, experimental methods and type of metal ions being used..$^{59}$ As shown by Machado et al., the inactivated biomass of Saccharomyces cerevisiae displayed a greater $\mathrm{Zn}^{2+}$ and $\mathrm{Ni}^{2+}$ accumulation, but a similar accumulation of $\mathrm{Cu}^{2+}$ than in the live biomass. ${ }^{16}$

$\mathrm{Cd}(\mathrm{II})$ adsorption results of dead and live cells may suggest that the dead biomass is a preferred alternative for remediating Cd(II) in a contaminated environment. Furthermore, the dead biosorbent possessed some advantages: no requirements for nutrients, no toxicity limitations, easy recovery of metals, easy regeneration and reuse of biomass, and less affected by $\mathrm{pH}$ and temperature. ${ }^{\mathbf{6 0 - 6 2}}$ Despite the obvious advantages of using dead biomass over live biomass, many attributes of living microbes should be emphasized as well. Live strains could degrade organic pollutants and can adsorb, transport, complex and transform metals, metalloids and radionuclides, ${ }^{63}$ especially the use of live PGPR for remediating heavy metal contaminated soils. $^{64}$

\section{Conclusions}

The removal efficiencies and adsorption capacities of live and dead biosorbents of Cupriavidus necator GX_5, Sphingomonas sp. GX_15, and Curtobacterium sp. GX_31 are quite different and strongly affected by the initial Cd(II) concentrations. Whether the cells are living or dead, the adsorption capacity among strains can be listed as GX_31 > GX_15 > GX_5. SEM-EDX, FTIR analysis and adsorption studies indicate that both live and dead cells have the ability to adsorb Cd(II), but the dead biomass is superior to the live biomass within the experimental conditions tested, especially when the concentration of $\mathrm{Cd}(\mathrm{II})$ is low. However, to obtain more accurate results and apply them in practice, more strains should be employed to compare the remediation capacity between live and dead biosorbents for different metals, under a series of metal concentrations.

\section{Conflicts of interest}

There is no conflict of interest and all the authors are interested to publish the manuscript.

\section{Acknowledgements}

This work was supported by Agriculture Committee of Shanghai (2014/5-2). We are thankful to MS Yao Han for SEM and EDX analysis, and Prof. Bangshang Zhu for FTIR spectra analysis (Instrumental Analysis Center of Shanghai Jiao Tong University, Shanghai, China).

\section{References}

1 R. A. Wuana and F. E. Okieimen, ISRN Ecol., 2011, 2011, 120.

2 W. Zhou, D. Liu, H. Zhang, W. Kong and Y. Zhang, Bioresour. Technol., 2014, 165, 145-151.

3 M. Beldowska, A. Zgrundo and J. Kobos, Water, Air, Soil Pollut., 2018, 229, 168. 
4 G. C. R. Casagrande, C. dos Reis, R. Arruda, R. L. T. de Andrade and L. D. Battirola, Water, Air, Soil Pollut., 2018, 229, 116.

5 J. Marrugo-Negrete, J. Pinedo-Hernández and S. Díez, Environ. Res., 2017, 154, 380-388.

6 R. Strachel, J. Wyszkowska and M. Baćmaga, Water, Air, Soil Pollut., 2018, 229, 235.

7 J. Wang and C. Chen, Biotechnol. Adv., 2009, 27, 195-226.

8 J. Wang and C. Chen, Biotechnol. Adv., 2006, 24, 427-451.

9 Y. Cheng, C. Yang, H. He, G. Zeng, K. Zhao and Z. Yan, J. Environ. Eng. Div. (Am. Soc. Civ. Eng.), 2016, 142, C4015001.

10 K. Vijayaraghavan and Y. S. Yun, Biotechnol. Adv., 2008, 26, 266-291.

11 X. Ren, G. Zeng, L. Tang, J. Wang, J. Wan, H. Feng, B. Song, C. Huang and X. Tang, Soil Biol. Biochem., 2018, 116, 70-81.

12 C. Yang, J. Wang, M. Lei, G. Xie, G. Zeng and S. Luo, J. Environ. Sci., 2010, 22, 675-680.

13 B. Prapagdee, M. Chanprasert and S. Mongkolsuk, Chemosphere, 2013, 92, 659-666.

14 B. R. Glick, Biotechnol. Adv., 2010, 28, 367-374.

15 M. M. Areco, S. Hanela, J. Duran and S. Afonso Mdos, J. Hazard. Mater., 2012, 213-214, 123-132.

16 M. D. Machado, S. Janssens, H. M. Soares and E. V. Soares, J. Appl. Microbiol., 2009, 106, 1792-1804.

17 L. Velasquez and J. Dussan, J. Hazard. Mater., 2009, 167, 713716.

18 J. Tangaromsuk, P. Pokethitiyook, M. Kruatrachue and E. Upatham, Bioresour. Technol., 2002, 85, 103-105.

19 C. Xu, S. He, Y. Liu, W. Zhang and D. Lu, Chemosphere, 2017, 173, 622-629.

20 F. Huang, Z. Dang, C. L. Guo, G. N. Lu, R. R. Gu, H. J. Liu and H. Zhang, Colloids Surf., B, 2013, 107, 11-18.

21 J. Guo, X. D. Zheng, Q. B. Chen, L. Zhang and X. P. Xu, Curr. Microbiol., 2012, 65, 350-355.

22 L. Fang, P. Cai, W. Chen, W. Liang, Z. Hong and Q. Huang, Colloids Surf., A, 2009, 347, 50-55.

23 M. Oves, M. S. Khan and H. A. Qari, J. Taiwan Inst. Chem. Eng., 2017, 80, 540-552.

24 O. A. Mohamad, X. Hao, P. Xie, S. Hatab, Y. Lin and G. Wei, Microbes Environ., 2012, 27, 234-241.

25 X. J. Li, D. B. Li, Z. N. Yan and Y. S. Ao, RSC Adv., 2018, 8, 30902-30911.

26 Y. Huang, C. Yang, Z. Sun, G. Zeng and H. He, RSC Adv., 2015, 5, 11475-11484.

27 T. Fan, Y. Liu, B. Feng, G. Zeng, C. Yang, M. Zhou, H. Zhou, Z. Tan and X. Wang, J. Hazard. Mater., 2008, 160, 655-661.

28 H. J. He, Z. H. Xiang, X. J. Chen, H. Chen, H. Huang, M. Wen and C. P. Yang, Int. J. Environ. Sci. Technol., 2017, 15, 14911500.

29 J. Bai, X. Yang, R. Du, Y. Chen, S. Wang and R. Qiu, J. Environ. Sci., 2014, 26, 2056-2064.

30 T. Limcharoensuk, N. Sooksawat, A. Sumarnrote, T. Awutpet, M. Kruatrachue, P. Pokethitiyook and C. Auesukaree, Ecotoxicol. Environ. Saf., 2015, 122, 322-330.

31 P. Arivalagan, D. Singaraj, V. Haridass and T. Kaliannan, Ecol. Eng., 2014, 71, 728-735.
32 M. Oves, M. S. Khan and A. Zaidi, SaudiJ. Biol. Sci., 2013, 20, 121-129.

33 J. Cheng, W. Yin, Z. Chang, N. Lundholm and Z. Jiang, J. Appl. Phycol., 2016, 29, 211-221.

34 N. Masoudzadeh, F. Zakeri, T. bagheri Lotfabad, H. Sharafi, F. Masoomi, H. S. Zahiri, G. Ahmadian and K. A. Noghabi, J. Hazard. Mater., 2011, 197, 190-198.

35 P. Chakravarty, N. S. Sarma and H. Sarma, Chem. Eng. J., 2010, 162, 949-955.

36 E. Khadivinia, H. Sharafi, F. Hadi, H. S. Zahiri, S. Modiri, A. Tohidi, A. Mousavi, A. H. Salmanian and K. A. Noghabi, J. Ind. Eng. Chem., 2014, 20, 4304-4310.

37 Q. Zhai, F. Tian, G. Wang, J. Zhao, X. Liu, K. Cross, H. Zhang, A. Narbad and W. Chen, RSC Adv., 2016, 6, 5990-5998.

38 H. Doshi, A. Ray and I. L. Kothari, Curr. Microbiol., 2007, 54, 213-218.

39 Y. Lin, X. Wang, B. Wang, O. Mohamad and G. Wei, Ecotoxicol. Environ. Saf., 2012, 77, 7-17.

40 F. Huang, Z. H. Wang, Y. X. Cai, S. H. Chen, J. H. Tian and K. Z. Cai, Ecotoxicol. Environ. Saf., 2018, 157, 216-226.

41 M. Polak-Berecka, P. Boguta, J. Ciesla, A. Bieganowski, T. Skrzypek, T. Czernecki and A. Wasko, Appl. Microbiol. Biotechnol., 2017, 101, 3415-3425.

42 Y. Yang, M. Hu, D. Zhou, W. Fan, X. Wang and M. Huo, RSC Adv., 2017, 7, 18793-18802.

43 N. Chubar, T. Behrends and P. Van Cappellen, Colloids Surf., $B, 2008,65,126-133$.

44 X. Lu, X. J. Zhou and T. S. Wang, J. Hazard. Mater., 2013, 262, 297-303.

45 W. Huang and Z. M. Liu, Colloids Surf., B, 2013, 105, 113119.

46 S. S. Zamil, M. H. Choi, J. H. Song, H. Park, J. Xu, K. W. Chi and S. C. Yoon, Appl. Microbiol. Biotechnol., 2008, 80, 531544.

47 H. Wu, Q. Wu, G. Wu, Q. Gu and L. Wei, PLoS One, 2016, 11, e0151479.

48 J. Yu, M. Tong, X. Sun and B. Li, J. Hazard. Mater., 2007, 143, 277-284.

49 J. Pan, R. Liu and H. Tang, J. Environ. Sci., 2007, 19, 403-408.

50 N. N. N. A. Rahman, M. Shahadat, C. A. Won and F. M. Omar, RSC Adv., 2014, 4, 58156-58163.

51 G. Sathiyanarayanan, S. K. Bhatia, H. J. Kim, J.-H. Kim, J.-M. Jeon, Y.-G. Kim, S.-H. Park, S. H. Lee, Y. K. Lee and Y.-H. Yang, RSC Adv., 2016, 6, 96870-96881.

52 T. Wang, X. Zheng, X. Wang, X. Lu and Y. Shen, J. Environ. Radioact., 2017, 167, 92-99.

53 G. M. Gadd, Fungi and yeasts for metal accumulation, New York, McGraw-Hill, 1990, pp. 249-276.

54 G. W. Strandberg, S. E. II Shumate and J. R. Jr Parrot, Appl. Environ. Microbiol., 1981, 41, 237-245.

55 H. Li, Y. Lin, W. Guan, J. Chang, L. Xu, J. Guo and G. Wei, J. Hazard. Mater., 2010, 179, 151-159.

56 S. Silver and T. Phung le, J. Ind. Microbiol. Biotechnol., 2005, 32, 587-605.

57 D. H. Nies, FEMS Microbiol. Rev., 2003, 27, 313-339.

58 F. Huang, C. Guo, G. Lu, X. Yi, L. Zhu and Z. Dang, Chemosphere, 2014, 109, 134-142. 
59 T. Akar and S. Tunali, Bioresour. Technol., 2006, 97, 17801787.

60 N. R. Bishnoi and Garima, J. Sci. Ind. Res., 2005, 64, 93-100. 61 A. Hansda, V. Kumar and Anshumali, World J. Microbiol. Biotechnol., 2016, 32, 170.
62 E. V. Soares and H. M. Soares, Environ. Sci. Pollut. Res., 2012, 19, 1066-1083.

63 M. Fomina and G. M. Gadd, Bioresour. Technol., 2014, 160, 314.

64 H. Chauhan, D. J. Bagyaraj, G. Selvakumar and S. P. Sundaram, Appl. Soil Ecol., 2015, 95, 38-53. 